\title{
Images and performative vision in the Middle Ages
}

\section{Imágenes y visión performativa en la Edad Media}

\author{
Carla Maria BINO \\ Catholic University of the Sacred Heart, Milan \\ carla.bino@unicatt.it
}

Recibido: $18 / 05 / 2017$

Aceptado: 01/07/2017

\begin{abstract}
During the Middle Ages, images had to be tied to the truth. Otherwise, they were considered idols. And the idols are always dangerous and, therefore, banned. So, to be justified, the imago had to be true or really refer to truth. It follows that the images were not considered just objects 'to see', but were perceived as almost 'alive bodies', real bodies: they could act as if were actually present. This essay studies the image concept in Christian thought, with particular attention to Eastern Europe, in connection to the patristic and conciliar sources. The result is the shift of its ontological meaning: contrary to the mimetic idea of greek-hellenistic culture, the christian image is an 'impression of similarity'. This conceptual revolution implies change of visualization strategies, which are specifically performative: 'seeing the icon' is doing something which involves 'physically' the viewer, as if he came into a scene and became an actor.
\end{abstract}

Key words: Theory of representation; Cultural vision; Medieval images; Performative icon

Resumen: Durante la Edad Media, las imágenes tenían que estar atadas a la verdad. De lo contrario, eran consideradas ídolos. Y los ídolos son siempre peligrosos y, por lo tanto, prohibidos. Por eso, para ser justificada, la imago tenía que ser verdadera o realmente referirse a la verdad. De ello se desprende que las imágenes no eran consideradas simplemente objetos "para ver", sino que se percibían como casi "cuerpos vivos", cuerpos reales: podían actuar como si estuvieran realmente presentes. Este ensayo estudia el concepto de imagen en el pensamiento cristiano, con especial atención a Europa Oriental, en relación con las fuentes patrísticas y conciliares. El resultado es el cambio de su significado ontológico: contrariamente a la idea mimética de la cultura greco-helenística, la imagen cristiana es una "impresión de similitud". Esta revolución conceptual implica el cambio de estrategias de visualización, que son específicamente performativas: 'ver el icono' es hacer algo que implica "físicamente" al espectador, como si entrara en una escena y se convirtiera en actor.

Palabras clave: Teoría de la representación, visión cultural, imágenes medievales, icono performativo.

Contents: 1. A 'revolution' of the image 2. Image and imprint 3. Memory of the body, evidence of the event. 4. Face to face. Sources and Bibliography

\section{A 'revolution' of the image}

In the Middle Ages, images -whether material or immaterial (that is, images of memory, dreams, and visions, as well as those of language, including 
rhetorical and descriptive images)- are not simply to be looked at. ${ }^{1}$ They often have such great powers as to bring about miracles. ${ }^{2}$ In some cases they take the place of people so successfully that they are understood and perceived as bodies or as similar to bodies, and so they may move, speak, be hurt, bleed, or weep. ${ }^{3}$ In other cases they stand for situations and facts and as such belong to the future as much as to the past, but in showing themselves 'now' they are aoristic, since they render all time present. ${ }^{4}$ Ultimately, medieval images seem to be endowed with their own identity and with a living force which means that they are able to be truly present and to create continually a rapport with the viewer, who is thereby implicated and engaged. ${ }^{5}$ To put it succinctly, medieval images act. This capacity of theirs to act changes according to their function; it depends on what they want to achieve and to whom they are addressed. The particular function of an image, moreover, determines the form and appearance assumed by these images.

\footnotetext{
${ }^{1}$ On the meaning of imago see Jean-Claude SCHMITT, "La culture de l'imago", in Images médiévales, Annales. Histoire, Sciences Sociales, LI, 1996, 1, p. 3-36 and Les images dans les sociétés médiévales: pour une Histoire comparée, ed. by Jean-Marie SANSTERRE and JeanClaude SCHMITT, Turnhout, Brepols, 1999. On the alterity of medieval images between substance and vision see Jean-Claude SCHMITT, "Imago': de l'image à l'imaginaire", in L'image. Fonctions et usages dans l'Occident médiéval, Acts of the $6^{\text {th }}$ International Workshop on Medieval Societies, Centro Ettore Majorana, Erice, 17-23 ottobre 1992, ed. by Jérôme BASCHET and Jean-Claude SCHMITT, Paris, Le Léopard d'Or, 1996, p. 29-31; Jean-Claude BONNE, "Entre l'image et la matière: la choséité du sacré en Occident", in Les images dans les sociétés médiévales: pour une histoire comparée, Atti del colloquio internazionale (Roma 19-20 giugno 1998), ed. by Jean-Marie SANSTERRE and Jean-Claude SCHMITT, Bulletin de l'Institut Historique belge de Rome, LXIX, 1999, p. 77-111.

${ }^{2}$ See Art and Holy Powers in the Early Christian House, ed. by Eunice DAUTERMAN Maguire, Henry Maguire, Maggie J. DunCan-Flowers, Illinois Byzantine Studies, II, Urbana and Chicago, University of Illinois Press, 1989; Henry MAGUIRE, Magic and the Christian Image, in Byzantine Magic, ed. by Henry MAGUIRE, Dumbarton Oaks Research Library and Collection, Washington D. C., Harvard University Press, 1995, p. 51-71; Luigi CANETTI, "Suxerunt oleum de firma petra'. Unzione dei simulacri e immagini miracolose tra Antichità e Medioevo", in Studi di Storia del Cristianesimo. Per Alba Maria Orselli, ed. by Luigi CANETTI et al., Ravenna, Longo, 2008, p. 61-87.

${ }^{3}$ On the relationship between images and bodies see Henry MAGUIRE, The Icons of Their Bodies. Saints and Their Images in Byzantium, Princeton, Princeton University Press, 1996.

${ }^{4}$ On this subject see Carolly ERICKSON, The Medieval Vision. Essays in History and Perception, Oxford, Oxford University Press, 1976; Jean-Marie SANSTERRE, "Visions et miracles en relation avec le crucifix dans récits des $\mathrm{X}^{\circ}-\mathrm{XI}^{\circ}$ siècles", in Il Volto Santo in Europa. Culto e immagini del Crocifisso nel Medioevo, Atti del convegno internazionale di studi (Engelberg, 13-16 settembre 2000), ed. by Michele Camillo FERRARI and Andreas MEYER, Lucca, Istituto Storico Lucchese, 2005, p. 387-406.

${ }^{5}$ On this topic see, at a minimum, David FreEdBerg, The Power of Images. Studies in the History and Theory of Response, Chicago, Chicago University Press, 1989; Peggy MCCRACKEN, "Miracles, Mimesis, and the Efficacy of Images", Yale French Studies, CX, 2006, p. 47-57. On image and presence see William LOERKE, 'Real Presence' in Early Christian Art, in Monasticism and the Arts, ed. by T. VERDON, Syracuse, Syracuse University Press, 1984, p. 29-51; on 'real presence' see the thought-provoking article by Bob SCRIBNER, "Popular Piety and Modes of Visual Perception in Late-Medieval and Reformation Germany", The Journal of Religious History, XC, 1989, 4, p. 448-469.
} 
In the Middle Ages sight was not simply one of five senses. It was a physical encounter, a point of contact between rays sent from both the viewing eye and the viewed object. ${ }^{6}$ If sight entails contact, seeing is a complex, concrete action which involves all the senses of the body (touch, smell, hearing, taste) at the same time (synaesthetically). Seeing, in other words, is an action which demands internal discipline, a 'posture' of the mind as well as of the body, and an intentional gaze which generates a particular perspective. Seeing means, therefore, coming into contact with an image and activating it; to put it more eloquently, it means taking part in a 'stage of the senses', formed of actions and relationships. Seeing is a performance.

In recent years the idea of 'performative vision' has been at the heart of international studies of the Middle Ages. Such studies, embracing an interdisciplinary approach and re-reading sources and documents from a variety of different perspectives, have been particularly concerned with the meaning of representation and questions of how representation works, in an attempt to rethink radically the status of images and their relationship with the spectator. ${ }^{7}$ From such studies distinguishing features have come to light of what we might call the 'visual culture' of the Middle Ages, the principles of which are taken from theories of Christian representation. This original, reasoned, systematic, theoretical body of knowledge is based upon solid epistemological foundations and on the key tenets of the theology of the Incarnation. The latter, which contains a precise concept of imagery, has even been defined as an imagistic theology', that is as a theology which is imaginative in the etymological sense of the word. ${ }^{8}$ Christian thought presupposes the paradox of what Didi-Huberman calls the "open image", namely the paradox of the incarnate image which is both invisible and visible. ${ }^{9}$ Importantly, Christian imagery along such lines challenges

\footnotetext{
${ }^{6}$ On this topic see David LindBerg, The Science of Optics, in Science in the Middle Ages, ed. by David LindBERG, Chicago, University of Chicago Press, 1978, p. 338-368 e ID., Studies in the History of Medieval Optics, London, Variorum Reprint, 1983.

${ }^{7}$ See amongst the most recent contributions to this topic, Kathryn STARKEY, Reading the Medieval Book. Word, Image and Performance in Wolfram von Eschenbach's Willehalm, Notre Dame, University of Notre Dame Press, 2004; The Mind's Eye, Art and Theological Argument in the Middle Ages, ed. by Jeffrey HAMBURGER and Anne-Marie BOUCHÉ, Princeton University Press, Princeton, 2006; Seeing the Invisible in Late Antiquity and the Early Middle Ages, Papers from «Verbal and Pictorial Imaging: Representing and Accessing Experience of the Invisible, 400-1000», (Utrecht, 11-13 December 2003), ed. by Giselle DE NIE, Karl F. MORRISON, Marco Mostert, Turnhout, Brepols, 2005; Jessica BRANTLEY, Reading in the Wilderness. Private Devotion and Public Performance in Late Medieval England, Chicago, University of Chicago Press, 2007; Visualizing Medieval Performances. Perspectives, Histories, Contexts, ed. by Elina Gertsman, Aldershot, Ashgate, 2008. Jill Stevenson, Performance, Cognitive Theory, and Devotional Culture. Sensual Piety in Late Medieval York, New York, Palgrave Macmillan, 2010.

${ }^{8}$ See Barbara Newman, God and the Goddesses. Vision, Poetry, and Belief in the Middle Ages, Philadelphia, University of Pennsylvania Press, 2003, p. 294-304.

${ }^{9}$ See George Didi-HuBERMAN, L'image ouverte: motifs de l'incarnation dans les arts visuels, Paris, Gallimard, 2007, especially "Ouverture", p. 25-63 and the second essay "La couleur de chair, ou le paradoxe de Tertullien ", p. 97-152.
} 
and overturns the analogical status and functioning of the Classical image; the image as copy, replica, or translation of an original is unable to signify a world order 'revealed in an image'. The abyss of metaphysical duality gives way to the mystery of the unity of two Persons in one, and in so doing the material inferiority of Greek imagery is found to be ontologically and epistemologically unable to meet a flesh-and-blood gaze which is invited to look beyond. Revelation replaces and invalidates reproduction.

This theoretical paradigm shift is part of both theology, which concerns thinking about God, and divine economy, which devotes itself to the visible and experiential translation of that mode of thinking and to its concrete revelation and deployment throughout history. In both cases the redefining of the concept of the image takes place through an identical process which entails moving from the idea of an imitative copy to the idea of a demonstrative form. The semantic field which Christian thought will use to describe images will no longer be that of 'mimesis', but instead that of 'inscription', or, even more explicitly, that of 'impression'. Linking imprint and image meant confronting the question of the extent to which representation ought to be considered true, because of the necessary connection forged between the real existence of a subject and the real presence of its visible, perceptible trace: in short, the real presence of a 'real absence'.

It is with such question and connections that this essay is concerned.

\section{Image and imprint}

The redefining of the concept of the image came about as a result of the first Council of Nicaea in 325 AD. The same Council was responsible for the confutation of the Arian heresy which held that God was a monadic unity and that $\mathrm{He}$, alone, was eternal, uncreated, true, immortal, with nothing and no one identical or even similar to Him. In this absolute and transcendental solitude there is no space for the other Persons of the Trinity and indeed when St Paul explains that "the Son is the image of the invisible God" (Col. 1.15) he is, according to the Arian heresy, in fact preaching difference and dissimilitude within the Trinity since the image, understood in the Greco-Hellenistic tradition of Platonic and neo-Platonic derivation as a copy, is necessarily inferior to the original. It was St Athanasius who explained that saying that the Son is the image of the Father means saying that the Son reveals the Father, or that paternity is one of the fundamental characteristics of the first Person of the Trinity and is revealed to us by the Son. In other words, eternal paternity is one of the few positive affirmations that humans can make about God because it is revealed by the eternal Sonhood: "before all worlds [...], the first Person is Father of his Son without beginning and coeternal [...]. But since the quality of the Father and of the Son means an identity of essence, it must also affect how images are understood". ${ }^{10}$ The image within Trinitarian doctrine thus undergoes a radical

\footnotetext{
${ }^{10}$ Nicolas OzoLINE, La théologie de l'icône, in Nicée II, 787-1987. Douze siècles d'images religiueses, Actes du colloque international Nicée II tenu au collége de France, (Paris, 2-4 octobre 1986), ed. by François BOESPFLUG et Nicolas LOSSKY, Paris, Les éditions du Cerf,
} 
rewriting; it switches from having been understood as a result of reproduction (and therefore as facta) to being considered intrinsic and begotten. In other words, the relationship between Father and Son is no longer that maintained by Plotinus's One with its first emanation and is not based on differences of being or on degrees of participation in being, since the image of God does not partake of God, but rather is God. In short, the Son is now a homoousian image, perfect and consubstantial with its own model. With the new, revolutionary, and paradoxical notion of the 'perfect image' we are faced with what Schönborn defines as "a fabric of new concepts" " which entail the decline of the Classical conception of the image as a copy inferior to the original. Significantly, the dwindling of this participatory, reproductive understanding of the image coincides with the introduction of the idea of the image as impression, widely attested by the use of words such as typos and charakter and verbs such as graphein (hypographein perigraphein), charassein, and typein. St Basil the Great explains well the epistemological, gnostic implications of this change when he says that the Son is charakter or morphe (form) of the hypostasis of the Father and clarifies that

He who has learned to know the Son has received in his heart 'the image of his [Father's] person' (charaktéra) through the knowledge of the Son. For, all the attributes of the Father are beheld in the Son, and all the attributes of the Son belong also to the Father, since both the whole Son remains in the Father and has the whole Father in Himself. Therefore, the person of the Son becomes, as it were, the form (morphè) and face (pròsopon) of the knowledge of the Father, and the person of the Father is known in the form of the Son, although the individuality observed in them remains for the clear distinction of their persons (menoùses idiòtetos). ${ }^{12}$

The same impression-based understanding also forms the basis of the patristic doctrine of man made in the image and likeness of God. As St Cyril of Alexandria says, "through the Spirit [man] was sealed (katesphraghizeto) unto the Divine Image [...]. For the Spirit at once began both to put life into His formation and in a Divine manner to impress (charakteras enesemainen) His own Image thereon". ${ }^{13}$ God creates man by 'imprinting' on him His image and the

1987, p. 408. Translator's rendition of "Avant tout commencement [...] la première personne est Père de son Fils sans commencement et coéternel [...]. Mais puisque la qualité de Père et de Fils signifie l'identité d'essence, cela doit aussi se répercuter sur la notion d'image".

${ }^{11}$ Christoph SchÖNBORn, God's Human Face: The Christ-Icon, trans. by Lothar KrAUTH, San Francisco, Ignatius Press, 1994, p. 17.

${ }^{12}$ St BASIL THE GREAT, Letters, 2 vols, trans. by Sister Agnes Clare WAY, Washington, DC, The Catholic University of America Press, 1965-1969, vol. one, letter 38, p. 96. This letter is sometimes erroneously attributed to Gregory of Nyssa. See also Patrologiae cursus completus. Series graeca, ed. by Migne, Migne, Paris, 1857-1866, 161 vols (from now on PG), vol. 32, col. 329A-340C.

${ }^{13}$ PG 73, col. 204D. Translation from S. CYRIL, ARChBISHOP OF ALEXANDRIA, Commentary on the Gospel According to S. John, A Library of the Fathers of the Holy Catholic Church, 2 
image of God is the Son. God creates man, therefore, from Himself, from that which $\mathrm{He}$ is, from his morphe, and yet fully other than Himself. This means that mankind, as part of creation, is not coessential with God, but, since individuals carry within themselves the impression of the image of God they are in relationship with God and similar to God. Alongside the 'perfect' image, the homoousian Son, we have the 'resembling' image, man as homoios. The first is a form (morphe) of hypostasis, the second is an imprint of the form and, because it is facta, enters into the order of time and becoming. Human beings can, nonetheless, decide to what extent the resemblance to the image is activated because they are free. Activating the similarity with God means rendering visible the traits of the image imprinted in the individual from the moment of creation and revealed in the Incarnation of the Son. As St Irenaeus of Lyons explains:

In the former times it was said indeed that Man was made in the Image of God, but it was not revealed. For the Word was yet invisible, after Whose Image Man had been made. And for this cause, you see, he easily cast off also the resemblance of Him. But when the Word of God became flesh, He made both good. For He both truly revealed the Image, Himself having become that very Thing, which the Image of Him was: and He firmly established the resemblance, by causing man to partake of His own complete likeness to the Invisible Father, through the Visible Word. ${ }^{14}$

With the coming of Christ in the flesh, the perfect image which before was invisible takes on the nature of man, created according to God's own image, and thus reveals the truth, or rather the original 'type' of the image of God (prototypos) imprinted in man at the moment of creation. This revelation is in fact the fulfillment of an image of perfect resemblance: Christ is at the same time a living image of the paternity of God and a new imprint (hypotyposis) of humanity, re-made, re-impressed, and,therefore, reformed re-formed.

It is evident that the key concept for understanding the new way of appreciating images is that of the 'impression', which oscillates between the two poles of mould (seal, character) and imprint, or rather that which is imprinted, engraved, or stamped. Terms such as typos, sphraghis, or charakter may signify either the mould or the imprint, depending on whether they have an active role or are understood as the result of an action. ${ }^{15}$ Between that which imprints and that

vols, Oxford and London, James Parker and Co., 1874-1885, vol. one, p. 141. See also Walter BURGHARDT, The image of God in Man according to Cyril of Alexandria, Washington D. C., The Catholic University of America Press, 1957.

${ }^{14}$ Fives Books of S. Irenaeus, bishop of Lyons, Against Heresies, A Library of Fathers of the Holy Catholic Church, trans. by John KeBLE, Oxford \& London, James Parker and Co., 1872, book 5, chapter 16, paragraph 2, p. 488.

${ }^{15}$ The imprinted merit of the icon is widely attested also by the Greek Fathers, as is easily evinced from a brief glance at the Lexicon of Greek Patristics which provides a wide-ranging examination of the words sphraghis, typòs, ypotyposis, charaktèr, and, finally, eikôn. See the individual lemmas in A Patristic Greek Lexicon, ed. by LAMPE, Oxford, Clarendon Press, 1961. 
which has been imprinted (between the mould and the imprint) lies action and Christian images are always in an active relationship. It is, then, possible to describe the Christian image as in itself both 'relative' and 'transitive': in a word, agens.

The theology of images circles around a tripartite performative articulation of the image: the perfect image, images of resemblance, and the image of perfect resemblance. This theology, which contains within it the whole system of thought of Christian representation, is the essential basis from which to consider the form and function of man-made images, that is, icons.

\section{Memory of the body, evidence of the event}

Since Christianity is concerned with the explosive newness of a God who chooses to relate to humans not only through the Word, but even through the Flesh, it makes the visible a stage for the real, historical presence of the invisible; the image in the form of kata physin (truth revealed by nature) becomes incarnate and establishes representation, eikon kata technen. Before the iconoclastic controversy, Christianity did not need to formulate a systematic theory of icons, simply because up until that point more attention had been paid merely to the importance that material images assumed for their viewers. ${ }^{16}$ The intrinsic status of the icon was explored only at a later date, in the context of debate over the relationships between truth, representation, and vision.

At that point, a number of questions arose, of which the following are representative: if the natural image has become visible and has thus revealed the ratio veritatis, are images of that image (i.e. icons) possible? How can drawings or paintings done by human hands in concrete matter be a means of accessing the invisible and therefore be a legitimate image of truth? Is the subject represented in the icon 'essentially' linked to the icon, meaning that something of the prototype is ontologically present in its material image? It was the attempt to answer such questions which started the long process of elaboration of a systematic way of thinking, beginning with the reanalysis of and reopening of discussions surrounding the concept of the image which Greek philosophy had attributed to material reality. ${ }^{17}$

By the end of the iconoclastic dispute, the concept of the icon had undergone a radical change and a definitive semantic shift which not only distanced it from

\footnotetext{
${ }^{16}$ A cogent excursus on the meaning of icons in Patristics can be found in Gerhart LADNER, "The Concept of the Image in the Greek Fathers and the Byzantine Iconoclastic Controversy", Dumbarton Oaks Papers, VII, 1953, p. 1-34. The reference work on the topic is still that of Ernst KITZINGER, "The Cult of Images in the Age before Iconoclasm", Dumbarton Oaks Papers, VIII, 1954, p. 83-150.

${ }^{17}$ The concept of the image reached ancient Christian thought on the one hand from Plato via Philo of Alexandria and St Paul and, on the other hand, drawing on Plotinus and Proclus as mediated via pseudo-Dionysius and John of Damascus (see LADNER, The Concept of the Image in the Greek Fathers, p. 5). See also Panayotis MiCHELIS, "Neo-platonic Philosophy and Byzantine Art", The Journal of Aesthetics and Art Criticism, XI, 1952, p. 21-45.
} 
the participatory, analogical, copy-oriented initial conception, but also brought into play the problem of the parameters of the truth of representation. ${ }^{18}$

The turning point came with the thought of both St Nicephorus of Constantinople (758-828 AD) and St Theodore of Studios (759-826 AD), to whom we owe the formulation of a theory of Christian imagery freed from neoPlatonic assumptions. Having abandoned any immanent, essentialist connection with the prototype, the concept of icons rested on a principle of relationality. Thus Nicephorus clarifies that a man-made image "is a likeness (homoioma) of an archetype which reproduces in itself (enapomattomene) by way of resemblance the entire form (eidos) of what is impressed upon it (entypoumenou), and which differs from it merely by the difference of substance with respect to matter". ${ }^{19}$

Similarly, the abbot of Studios explains that in "the case of the icon [...] there is present not even the nature of the flesh which is portrayed, but only its relation (schesis)" ${ }^{20}$ Icon and prototype are linked by a relationship of resemblance as regards visible appearance. When Nicephorus explains that it is in fact the visible appearance which is impressed as an imprint in the icon (the verb used is none other than enapomattein, meaning 'to leave an imprint'), he borrows from theological thoughts on the image the category of impression and the use of the semantic field of typos. For this reason he calls the subject which is represented entypoumenou, 'that what is impressed', thus articulating explicitly a formal relationship of resemblance concerning the economic context of the icon. From this a resemblance ensues which definitively disregards both participation of substance with the prototype and its presence:

If somehow the pattern should disappear, the relation does not end together with it [...]; for by the similarity (dia tes emphereias) and remembrance (mnemes) and form (morphe), [the icon] shows (emphanizousa) even the deceased (apoichomenon) as if he were present (os paronta) and it preserves (diasozei) the relation [with its model] as time goes along (symparekteinomenen). ${ }^{21}$

In this way the icon establishes its 'relativity' on precisely the fact of being a visualisation of the absent object which functions through mnemonic and inventive means. Icons preserve the memory of the form and offer a representation of it without a break in continuity of time, thereby demonstrating its

${ }^{18}$ See Charles BARBER, "From Image into Art: Art after Byzantine Iconoclasm", Gesta, XXXIV, 1995, 1, p. 5ff. See also Kenneth PARRY, Depicting the Word: Byzantine Iconophile Thought of the Eighth and Ninth Century, Leiden, Brill, 1996, p. 191-201.

${ }^{19}$ PG 100, col. 277A. English translation from Paul J. ALEXANDER, The Patriarch Nicephorus of Constantinople: Ecclesiastical Policy and Image Worship in the Byzantine Empire, Oxford, Clarendon Press, 1958, p. 199.

${ }^{20}$ The English translations here and subsequently are taken from ST THEODORE THE STUDITE, On the Holy Icons, trans. by Catharine P. ROTH, New York, St Vladimir's Seminary Press, 1981. This quotation on p. 33.

${ }^{21}$ PG 100, col. 280A. Translation from AlEXANDER, The Patriarch Nicephorus, p. 200. 
resemblance with the absent archetype as if that archetype were present. In other words, the icon renders present its relationship with its model by referring to it, or rather, by indicating to the gaze the direction in which to look in order to perceive the resemblance.

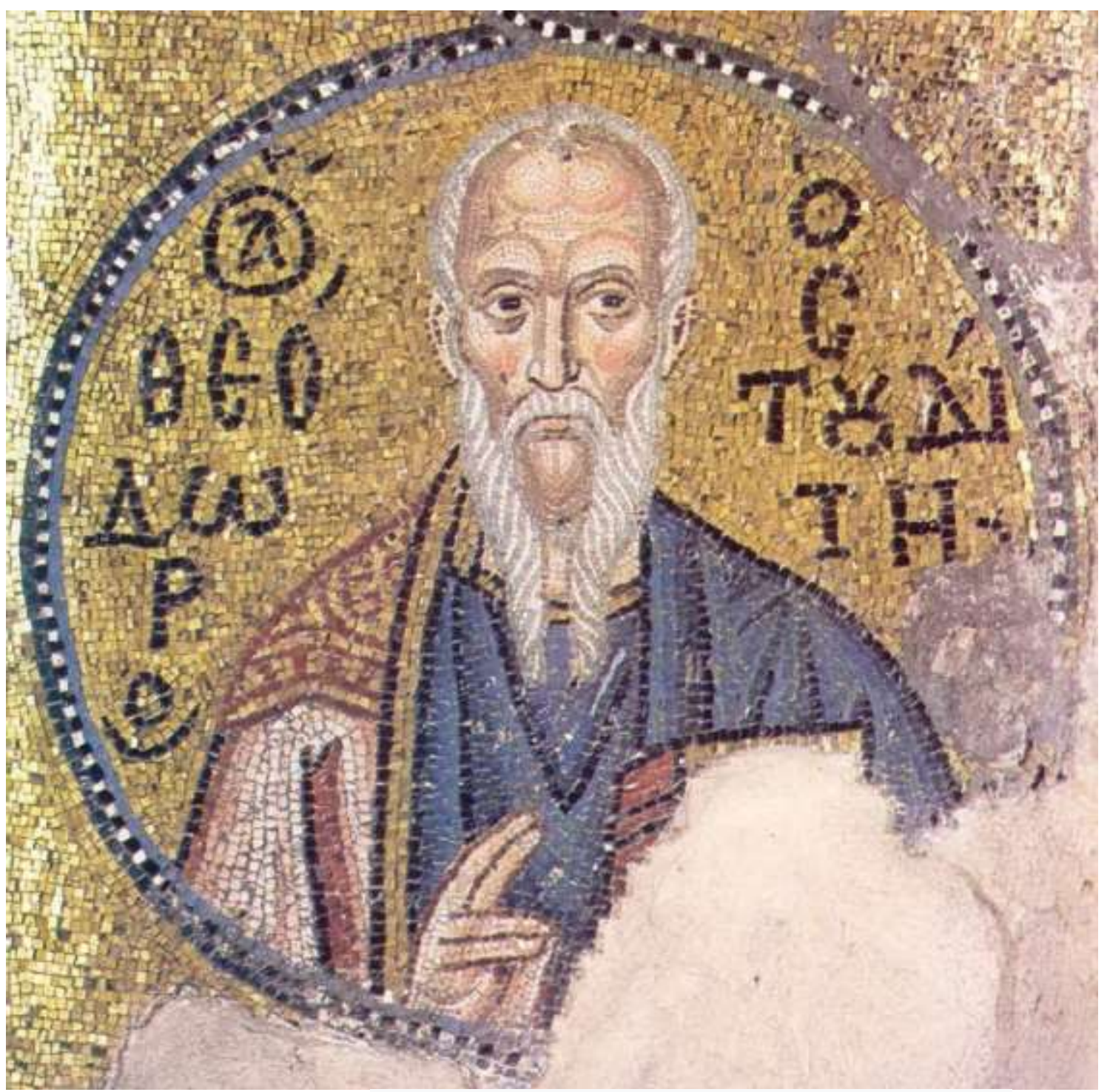

Fig. 1. St Theodore of Studios, 11th-century mosaic from Nea Moni Monastery, Chios. Image from Wikipedia: https://en.wikipedia.org/wiki/Theodore the Studite

Even Theodore reiterates that icons are an impression (hypotyposis, and in the course of the treatise he also uses terms such as sphraghis, typos, ektypoma, and enapomagma, all of which belong to the same semantic field) of the characteristics (charaktera) of the prototype. Yet for the Studite impressions guarantee the correct transmission of a resemblance which is not only formal but personal: "Is not every image a kind of seal (sphraghis) and impression (entyposis) bearing in itself the proper appearance of that after which it is named? For [...] we call the image of Christ 'Christ' because it is also Christ, yet there are 
not two Christs." 22 The man-made image is not, thus, a copy of the being in dead matter or the shadowy presence of the hypostasis which to an ever lessening degree remains in it, but is, rather, the impression of charaktera which constitute the visible aspect of a specific individual.

Changing the conception of the icon in itself means redefining its function. Indeed, if on the basis of immanent, neo-Platonic conceptions the icon participates in the nature of the subject, it follows that the icon has great weight in theological and sacramental terms: God is truly present in the icon. ${ }^{23} \mathrm{In}$ contrast, the argument that the icon does not partake of divine nature and thus is not a conduit for divine presence entails the assertion that the icon no longer has any sacramental value, but serves only as a memory aid: in the words of Theodore, "the depicted image is for us [...] a useful memory [hypomnema soterion] which shows us Christ at birth, in his baptism, performing miracles, on the Cross, in the tomb, risen, and ascending to heaven". ${ }^{24}$

The icon, in this case, preserves the memory of God incarnate, revealing the imprint of his aspect to mankind. Thus the icon is a witness - literally, a martyr that this event really happened in space and time.

The icon, to conclude, is both memory of the body and evidence of an event.

\section{Face to face}

The eventual understanding of the icon as imprint provided a definitive answer to the main problems underlying the relationship between truth, representation, and vision. The conception of impression resolved three key questions: firstly, the doubt cast on the real existence of the prototype and consequently the guarantee of respect for the ratio veritatis in the icon, which in this way was definitively placed in opposition to idols and idolatry; secondly, the role of icons recognised as a medium closely connected to their ontological status as 'relative'; thirdly and finally, the modality and meaning of vision and therefore also the performative quality of the gaze and the new relationship established between icon and spectator. Each of these points must be considered in turn.

The first bone of contention, that concerning ratio veritatis, had been the main battleground between iconoclasts and iconophiles. The former busied themselves with finding the 'true icon' and thus granted images an ontological, essentialist status, with the necessary result being the repudiation of material, man-made images, which given their failure to be true were deemed to be unavoidably idolatrous. Understanding the icon as impression, and the principle of relationship linked to that of resemblance resolved the impasse, since the

\footnotetext{
${ }^{22}$ Ibid., col. 337C; On the Holy Icons, p. 28.

${ }^{23}$ The problem of the 'sacramental' value of images (which renders the divine present in a similar way to the Eucharist) is one of the most complex and interesting problems underlying the conception of Christian representation. See Carla BINO, Dal trionfo al pianto. La fondazione del teatro della misericordia nel Medioevo, Milano, Vita e Pensiero, 2008, p. 105-145 and EAD., Il dramma e l'immagine. Teorie cristiane della rappresentazione (II-XI sec.), p. 169-175 and p. 212-216.
}

${ }^{24}$ PG 99, col. 456BC. (Translation autor's own.) 
necessity of a formal cause of resemblance -the mould of the imprint- meant that the truth of the subject and its real existence were undeniable. In other words, the truth of the icon in itself was no longer under discussion, but debate instead centred on the truth of that which was imprinted upon the icon. The questions arising included whether it was true that Christ was human and divine and that he had existed historically in the flesh, and whether that flesh were true, visible, tangible, and empirical.

If all these questions are answered in the affirmative then icons are legitimate because they are placed in relation to that truth and are the impression of resemblance to that truth. For this reason saying the name of an icon is an affirmation of a homonymic relationship which does not serve simply to identify the subject, but means recognising the very existence of that subject. The difference between icons and idols lies precisely in the following distinction. An idol is not an imprint of something that is real; it has no formal cause and thus has nothing with which to be related, since it does not refer to a truth but to 'something imagined'. Since idols are not based on a relationship of resemblance, they are self-sufficient and exhaust the gaze in themselves, unlike icons which call for a relative, moving gaze, a gaze which goes through and beyond. Icons, in contrast to idols, demand a prospective gaze which looks through the re-presentative medium.

Basing the status of the icon on a relationship of resemblance and homonymy with the prototype, whilst never losing sight of the essential difference between the two, meant recognising that icons perform the role of cognitive medium of a subject which is not ontologically present. Icons did not function on the basis of a mimetic principle involving copies and copying, nor on the basis of an 'analogical duplication', but rather on the basis of a relationship with something which exists. In this way seeing the resemblance in the icon meant being able to relate to the prototype. Granting the icon the specificity of an imprint necessitated placing as a guarantor of the relationship of resemblance something that is real in a physical and tangible sense, that is, a mould which is present in the icon only through the imprinted form. In other words, it necessitated recognising that icons work through the presence of a trace related to an absent subject, a trace which renders the prototype present in time and space but not in substance.

The metaphor of a mould which is imprinted served to justify the very coexistence of presence and absence; by leaving an imprint, the mould does indeed leave behind a form which is defined by empty space, by the absence of the mould. Thus the absence of the body is transformed into the visible presence of a trace of the body. The sphere of memory, too, is called upon, since the imprint can be understood as the memory of a body, or, rather, as that which remains as witness to its true, historical presence. The imprint seems to declare that the body was once really present. If an impression is the formal materialisation of an absence, icons can be understood as the sensual manifestation of an absence that is, ultimately, visible, tangible, and empirical.

In this way we come to the newness of performative vision which is the corollary of a tactile, experiential dimension of sight. Christian thought cannot 
disregard the concrete, real experience of a God who, being incarnate, offers Himself as similarly concrete and real. In this context, the icon as imprint resolves the relationship between visibility and invisibility by linking it to the relationship between tangibility and intangibility. The culture of impression, tactile visuality, and the theory of extramissive sight, all typical of Byzantium in that period, thus coalesce. The tangibility of the present object is more potent because of its visibility, since this allows physical recourse to the absent subject, which in turn is more easily conceivable as intangible than as invisible. ${ }^{25}$ Paradoxically, the icon as imprint is imbued with profound materiality, since the manifest and material resemblance (the palpable, tangible, sensual form of the imprint) compensates for the icon's lack of essence (the absence of the mould). ${ }^{26}$

The icon must, therefore, be experienced through multisensory vision, that is through a gaze which involves all the senses (sight, sound, touch, taste, hearing) simultaneously ${ }^{27}$ For this reason icons seem to be endowed with their very own corporeality and they can give the impression that the divine is present in the moment of vision and enters into contact facies ad faciem with the viewer. In this respect it is possible to describe the relationship between icon and onlooker as a sensory performance, as a synaesthetic experience composed of light, incense, song, and action, and the mimesis can be understood as 'imitation of presence'.

Icons are more than a window onto another world. Seeing an icon means meeting the form of the prototype, recognising the resemblance, and 'going towards' the absent subject as if it were present. If, then, that which is absent is understood as a subject that was once present, the mimesis is also commemorative re-enforcement of presence since formal resemblance activates the memory of the historical truth of the events that have taken place. Ultimately, if the idea of the icon as mnemonic trace resolves the problem of divine presence, the idea of the icon as performative satisfies the necessity of physical contact with the divine.

'Presence' and 'physical contact' with the divine are the defining characteristics of a performative, multisensory vision of icons. This vision is firmly rooted in experiential networks of pilgrimage and thus in the relationship between 'that which remains' (relics) and with memory as attested since the fourth century. ${ }^{28}$ The imprinted icon replaces real presence with an illusion of

\footnotetext{
${ }^{25}$ See Bissera Pentcheva, The Sensual Icon: Space, Ritual, and the Senses in Byzantium, University Park, Pennsylvania State University Press, 2010, p. 636.

${ }^{26}$ See Liz JAMES, "Sense and sensibility in Byzantium", Art History, XXVII, 2004, p. 523537. See also Icon and Word: The Power of Images in Byzantium, Studies presented to Robin Cormach ed. by Antony Eastmond and Liz James, Aldershot, Ashgate, 2003.
}

${ }^{27}$ See PentcheVA, "The Performative Icon", The Art Bulletin, LXXXVIII, 2006, 4, p. 631655. On the experience of art in Eastern Christianity see, at the very least, Anthony CUTLER, "The Right Hand's Cunning. Craftsmanship and the Demand for Art in Late Antiquity and the Early Middle Ages", Speculum, LXXII, 1997, p. 971-994; Thomas F. MATHEWs, The Clash of Gods. A Reinterpretation of Early Christian Art, Princeton, Princeton University Press, 1993, p. 95-95 and p. 136-137.

${ }^{28}$ Suffice it to reread Jerome's description of the physical and emotional attitude of his friend St Paula in front of the Cross in Jerusalem and the manger in Bethlehem. This account 
presence; it frees itself from the cult of relics and makes the discipline of eye and body the defining feature of Byzantine visual piety. From this perspective, prayer, genuflexion, kisses, and embraces are concrete actions which enable access to a transcendental sphere.

Paradoxically, it is as if the gaze started from sensory contact with the image of a body which is elsewhere and thus presupposed an intimate, real act of seeing, formed first and foremost of hands and both; only then, once presence had been ascertained by the senses, was the gaze able to go beyond. It is the multisensory gaze which breathes life into the image and renders it present, simultaneously conferring meaning on the image and fulfilling its function. It is the gaze which is responsible for the efficacity of icons which offer only indications of relationship and not the absolute guarantees granted by real presence, essential participation, or sanctification. Once icons are no longer conceived as objective, but as subjective since they act as a cognitive medium, they call for a gaze which allows them to function in a relative, relational fashion, as pros ti; a gaze, that is, which knows both how to act upon the image and how to let the image act upon the gaze.

The imprinted icon by itself does not communicate anything; communication starts only through what Mondzain has called a "commerce of gazes", or rather the active exchange of vision, within the performative power shared by gaze and object. ${ }^{29}$ This commerce of gazes contrasts with the univocal position of the gaze of a consumer, which is totally immersed by the object which it sees and in which it remains trapped. The latter gaze is enchained and petrified, and thus static, totalising, and inert; it does not desire to see beyond surface appearances and, indeed, confuses that which is visible - the eikon- and that which appears the eidolon.

Icons, in contrast, committed the gaze to the real absence of God.

Icons filled the gaze with desire.

$$
* * *
$$

recreates the strong sense of a continual commemoration and of a relationship in the presence of the divine, because of which the faithful is so assorbed in the repetition of events as to live them out in the first person. Finding oneself in front of the Cross is seeing the Lord as if he were hanging on the tree ("Prostrataque ante Crucem, quasi pendentem Dominum cerneret", JEROME, Epistola 108, Patrologia cursus completus. Series prima [latina], ed. by MignE, Migne, Paris, 1844-1865, 221 vols (vol. 22, col. 883, paragraph 697). The workings of experiential vision are illustrated well by Gary VIKAN, "Pilgrims in Magi's Clothing: The Impact of Mimesis on Early Byzantine Pilgrimage Art", in The Blessing of Pilgrimage, ed. by Robert OusTERHOUT, Urbana-Chicago, University of Chicago Press, 1990, p. 97-107; also relevant is Grace FRANK, "The Pilgrim's Gaze in the Age before Icons", in Visuality before and beyond the Renaissance: Seeing as Others Saw, ed. by Robert NELSON, Cambridge, Cambridge University Press, 2000, p. 98-115, and Glenn PEERS, Sacred Shock. Framig Visual Experience in Byzantium, University Park, The Pennsylvania State University Press, 2004, p. 18-24.

${ }^{29}$ See Marie-Jose MondzAin, Le Commerce des regards, Paris, Seuil, 2003 and also MarieJose MondZAIN, "What Does Seeing an Image Mean”, Journal of Visual Culture, IX, 2010, p. 307-315. 


\section{Sources and Bibliography}

\section{Sources}

Fives Books of S. Irenaeus, bishop of Lyons, Against Heresies, A Library of Fathers of the Holy Catholic Church, trans. by John KEBLE, Oxford \& London, James Parker and Co., 1872.

ST BASIL THE GREAT, Letters, 2 vols, trans. by Sister Agnes Clare WAY, Washington, DC, The Catholic University of America Press, 1965-1969.

St CYRIL, ARCHBISHOP OF AlEXANDRIA, Commentary on the Gospel According to S. John, A Library of the Fathers of the Holy Catholic Church, 2 vols, Oxford and London, James Parker and Co., 1874-1885.

St TheOdORE THE Studite, On the Holy Icons, trans. by Catharine P. Roth, New York, St Vladimir's Seminary Press, 1981.

\section{Bibliography}

Art and Holy Powers in the Early Christian House, ed. by Eunice DAUTERMAN Maguire, Henry Maguire, Maggie J. DunCAN-Flowers, Illinois Byzantine Studies, II, Urbana and Chicago, University of Illinois Press, 1989.

BARBER, Charles, "From Image into Art: Art after Byzantine Iconoclasm", Gesta, XXXIV, 1995, 1, p. 5-10.

BINO, Carla, Dal trionfo al pianto. La fondazione del teatro della misericordia nel Medioevo, Milano, Vita e Pensiero, 2008.

BINO, Carla, Il dramma e l'immagine. Teorie cristiane della rappresentazione (II-XI sec.), Firenze, Le Lettere, 2015.

BONNE, Jean-Claude, Entre l'image et la matière: la choséité du sacré en Occident, in Les images dans les sociétés médiévales: pour une histoire comparée, Atti del colloquio internazionale (Roma 19-20 giugno 1998), ed. by Jean-Marie SANSTERRE and Jean-Claude SCHMITT, "Bulletin de 1'Institut Historique belge de Rome", LXIX, 1999, p. 77-111.

Brantley, Jessica, Reading in the Wilderness. Private Devotion and Public Performance in Late Medieval England, Chicago, University of Chicago Press, 2007.

BURGHARDT, Walter, The image of God in Man according to Cyril of Alexandria, Washington D. C., The Catholic University of America Press, 1957.

CANETTI, Luigi, "Suxerunt oleum de firma petra'. Unzione dei simulacri e immagini miracolose tra Antichità e Medioevo", in Studi di Storia del Cristianesimo. Per Alba Maria Orselli, ed. by Luigi CANETTI et al., Ravenna, Longo, 2008, p. 61-87.

CuTLER, Anthony, "The Right Hand's Cunning. Craftsmanship and the Demand for Art in Late Antiquity and the Early Middle Ages", Speculum, LXXII, 1997, p. 971-994. 
DIDI-HUBERMAN, George, L'image ouverte: motifs de l'incarnation dans les arts visuels, Paris, Gallimard, 2007.

ERICKSON, Carolly, The Medieval Vision. Essays in History and Perception, Oxford, Oxford University Press, 1976.

FRANK, Grace, "The Pilgrim's Gaze in the Age before Icons", in Visuality before and beyond the Renaissance: Seeing as Others Saw, ed. by Robert NELSON, Cambridge, Cambridge University Press, 2000, p. 98-115.

FreEDBERG, David, The Power of Images. Studies in the History and Theory of Response, Chicago, Chicago University Press, 1989.

Icon and Word: The Power of Images in Byzantium, Studies presented to Robin Cormach ed. by Antony EASTMOND and Liz JAMES, Aldershot, Ashgate, 2003.

JAMES, Liz, "Sense and sensibility in Byzantium", Art History, XXVII, 2004, p. 523-537.

KITZINGER, Ernst, "The Cult of Images in the Age before Iconoclasm", Dumbarton Oaks Papers, VIII, 1954, p. 83-150.

LADNER, Gerhart, "The Concept of the Image in the Greek Fathers and the Byzantine Iconoclastic Controversy", Dumbarton Oaks Papers, VII, 1953, p. $1-34$.

LINDBERG, David, Studies in the History of Medieval Optics, London, Variorum Reprint, 1983.

LINDBERG, David, The Science of Optics, in Science in the Middle Ages, ed. by David LindBERG, Chicago, University of Chicago Press, 1978, p. 338-368.

MAGUIRE, Henry, "Magic and the Christian Image", in Byzantine Magic, ed. by Henry MAGUIRE, Dumbarton Oaks Research Library and Collection, Washington D. C., Harvard University Press, 1995, p. 51-71.

MAguire, Henry, The Icons of Their Bodies. Saints and Their Images in Byzantium, Princeton, Princeton University Press, 1996.

Mathews, Thomas F., The Clash of Gods. A Reinterpretation of Early Christian Art, Princeton, Princeton University Press, 1993.

MCCRACKEN, Peggy, "Miracles, Mimesis, and the Efficacy of Images", Yale French Studies, CX, 2006, p. 47-57. On image and presence see William LOERKE, "Real Presence' in Early Christian Art", in Monasticism and the Arts, ed. by Timothy VERDON, Syracuse, Syracuse University Press, 1984, p. 29-51.

MiCHELIS, Panayotis, "Neo-platonic Philosophy and Byzantine Art", The Journal of Aesthetics and Art Criticism, XI, 1952, p. 21-45.

MondZAin, Marie-Jose, Le Commerce des regards, Paris, Seuil, 2003.

MondZAIN, Marie-Jose, "What Does Seeing an Image Mean?", Journal of Visual Culture, IX, 2010, p. 307-315.

Newman, Barbara, God and the Goddesses. Vision, Poetry, and Belief in the Middle Ages, Philadelphia, University of Pennsylvania Press, 2003, p. 294304.

Nicée II, 787-1987. Douze siècles d'images religieuses, Actes du colloque international Nicée II tenu au Collége de France, (Paris, 2-4 octobre 1986), ed. by François BoESPFLUG et Nicolas LOSSKY, Paris, Les éditions du Cerf, 1987. 
PARRY, Kenneth, Depicting the Word: Byzantine Iconophile Thought of the Eighth and Ninth Century, Leiden, Brill, 1996, p. 191-201.

PEERS, Glenn, Sacred Shock. Framig Visual Experience in Byzantium, University Park, The Pennsylvania State University Press, 2004.

PentcheVA, Bissera, "The Performative Icon", The Art Bulletin, LXXXVIII, 2006, 4, p. 631-655.

PentcheVA, Bissera, The Sensual Icon: Space, Ritual, and the Senses in Byzantium, University Park, Pennsylvania State University Press, 2010.

SANSTERRE, Jean-Marie, "Visions et miracles en relation avec le crucifix dans récits des $\mathrm{X}^{\circ}-\mathrm{XI}^{\circ}$ siècles", in Il Volto Santo in Europa. Culto e immagini del Crocifisso nel Medioevo, Atti del convegno internazionale di studi (Engelberg, 13-16 settembre 2000), ed. by Michele Camillo FERRARI and Andreas MEYER, Lucca, Istituto Storico Lucchese, 2005, p. 387-406.

SCHMITT, Jean-Claude, “Imago': de l'image à l'imaginaire”, in L'image. Fonctions et usages dans l'Occident médiéval, Acts of the $6^{\text {th }}$ International Workshop on Medieval Societies, Centro Ettore Majorana, Erice, 17-23 ottobre 1992, ed. by Jérôme BASCHET and Jean-Claude SCHMITT, Paris, Le Léopard d'Or, 1996, p. 29-31.

SCHMITT, Jean-Claude, "La culture de l'imago", in Images médiévales, Annales. Histoire, Sciences Sociales, LI, 1996, 1, p. 3-36

SCHÖNBORN, Christoph, God's Human Face: The Christ-Icon, San Francisco, Ignatius Press, 1994.

SCRIBNER, Bob, "Popular Piety and Modes of Visual Perception in LateMedieval and Reformation Germany", The Journal of Religious History, XC, 1989, 4, p. 448-469.

Seeing the Invisible in Late Antiquity and the Early Middle Ages, Papers from "Verbal and Pictorial Imaging: Representing and Accessing Experience of the Invisible, 400-1000", (Utrecht, 11-13 December 2003), ed. by Giselle DE NIE, Karl F. MORRISON, Marco MOSTERT, Turnhout, Brepols, 2005.

StARKEY, Kathryn, Reading the Medieval Book. Word, Image and Performance in Wolfram von Eschenbach's Willehalm, Notre Dame, University of Notre Dame Press, 2004.

Stevenson, Jill, Performance, Cognitive Theory, and Devotional Culture. Sensual Piety in Late Medieval York, New York, Palgrave Macmillan, 2010.

The Mind's Eye, Art and Theological Argument in the Middle Ages, ed. by Jeffrey HAMBURGER and Anne-Marie BouchÉ, Princeton University Press, Princeton, 2006.

VIKAN, Gary, "Pilgrims in Magi's Clothing: The Impact of Mimesis on Early Byzantine Pilgrimage Art", in The Blessing of Pilgrimage, ed. by Robert OUSTERHOUT, Urbana-Chicago, University of Chicago Press, 1990, p. 97-107.

Visualizing Medieval Performances. Perspectives, Histories, Contexts, ed. by Elina GERTSMAN, Aldershot, Ashgate, 2008. 